\title{
Lyrical lessons: The potential of informative comedy music as supplementary teaching material
}

\author{
Dr. Matthew McKeague \\ Kutztown University of Pennsylvania \\ mckeague@,kutztown.edu
}

\begin{abstract}
The comedic arts have provided opportunities for humourists to spread information to audiences, sometimes intentionally and other times as a side effect while trying to create laughter. Educators have also found success incorporating comedy into the classroom with humorous activities. While research regarding comedy as a tool to spread information or educate audiences has focused primarily on literature, broadcast media, and film, the area of informative comedy implemented through music remains relatively unexplored. In this paper, the researcher defines 'informative comedy' and takes a critical literacy approach analysing song samples of comedy musician "Weird Al" Yankovic_-one of the notable comedic music artists in the 20th and 21st centuries - and discusses how his music could be used in a classroom setting. While comedy such as Yankovic's is not designed to be an educational tool, the researcher suggests that his songs could be used as supplementary materials in the classroom to reinforce concepts specifically regarding cultural issues through commentary as well as lessons in science and grammar. A central aspect of this exploratory paper involves Yankovic's mix of comedy and informative content focused on culture in the United States, using the popular music genre to convey ideas in ways that may be more palatable for wider audiences and that could be used to assist classroom instruction.
\end{abstract}

Keywords: comedy music, humour, education, critical literacy

\section{Introduction}

In order to discuss the potential of comedic music used as a supplementary reinforcement tactic in the classroom, the informative powers of both comedy and music must be addressed first. A brief review of the history of comedy music will then also be covered, as well as an introduction to musician "Weird Al" Yankovic. With this historical foundation and a review of the literature, a critical literacy approach can be applied to Yankovic's work, an approach looking for deeper 
meanings within media samples, the values portrayed in them, ideologies involved, and other teachable moments.

\subsection{Informative comedy}

Comedy often includes radical and subversive messages with the goals of educating audiences about issues, injustices, and topics that artists view as important. For example, late-night talk shows such as The Daily Show include political issues with a comedic spin and have been shown to cover similar levels of news information as mainstream broadcast journalism (Brewer \& Marquardt 2007; Feldman 2007), serving as a source of entertaining information since it first aired in 1996 in the United States. Similarly, comedic videos have also been shown to encourage audiences to think critically about manipulative media messages and weak arguments, for example when exposed to comedian Stephen Colbert's Super PAC video programming that "generated modest short-term issue recognition characteristic of online learning" (Warner et al. 2015). Comedy in the media has also been shown to be effective in challenging gender roles and femininity through characters who did not fit traditional molds such as Lucille Ball in the 1950s (White 2016) and in educating audiences about racial issues and reducing racial tension such as with Chris Rock and Dave Chappelle starting in the 1980s (Green \& Linders 2016). Furthermore, when researchers tested the effectiveness of a nonfiction comedy narrative regarding global poverty versus a somber documentary on the same topic, the humour narrative "produced significantly larger gains in awareness, knowledge, and actions" (Chattoo \& Feldman 2017). Because of the unique nature of comedy that contains potential educational material, the researcher has created the term 'informative comedy' to label this type of humour content. Using definitions of the words 'comedy' and 'information' from Merriam-Webster's dictionary, informative comedy will be defined as humorous entertainment that communicates knowledge or intelligence.

Though informative messages included in entertainment are partly a result of those in the industry wanting to appear credible by using accurate history, science, and math in their fiction (Pathmanathan 2014), there are also artists who want to teach audiences about topics they care about. For example, comedians such as Trevor Moore, Ricky Gervais and Tim Minchin use stand-up performance, media storytelling, and musical compositions with comedic lyrics to offer cultural commentary while spreading messages about science and mocking individuals who may be ignorant or hateful (Gunderson 2006; Pilcher 2010). By creating opportunities to laugh at serious issues, comedians desiring to affect crowds have the chance to challenge audiences' worldviews and to create introspective moments (McCarron \& Savin-Baden 2008). This is especially the case with parody, which, Hariman argues, "radically reveals that there are actors behind the masks... only through the shifts, slippage, and silliness of parody does the prior text become an obviously contrived performance" (Hariman 2008).

\subsection{Informative music}

Like comedy, music has a history of questioning authority and promoting counter-cultures with the power to create movements and spread ideas. As McDonald (1988) suggests, even though music may not always create a direct political response, lyrics informing audiences about issues can "contribute to a political perspective" (486) and "if the song creates awareness, a sense of consciousness about the topic addressed within the song, it will have served a useful purpose" 
(493).Throughout its past, music has incorporated political messages, from songs against the Vietnam War to recently promoting the Black Lives Matter activist movement discussing racial tensions in the United States. Rapper Kendrick Lamar's 2015 album To Pimp a Butterfly is an example that inspired other artists to speak out and join the cause including singer Beyoncé years later in her Super Bowl halftime show featuring Black Panthers (Zaru 2017; Dorian 2016). A segment of the music industry has also created social commentary through protest songs, such as Bob Dylan's critiques of unjust war, corporations, and the status quo (Wood 2015), perhaps most notably with his song "Blowin' in the Wind" in 1963 that supported the civil rights movement of African Americans.

Music, like comedy, has been shown to be able to break down and explain political issues in common sense ways that are more palatable to audiences, going back to the Greek playwright Aristophanes' Peace in 421 BCE (Odysseos 2001) via incorporation of everyday relevant events in emotionally moving ways (Brassett 2016). Considering the power that comedy and music have had in the past by creating awareness about societal issues and spreading information, this researcher posits that informative comedic music provides a unique opportunity to enlighten audiences in memorable ways, backed by further research on the impact of including comedy in a classroom setting.

\subsection{Combining the effects of comedy and music in the classroom}

Both comedy and music have also been found to be effective within educational contexts in and out of a classroom setting. In previous studies, comedy improved short-term issue recognition, something that corresponds to memory results of online learning (Warner et al. 2015; Southwick et al. 2002). Furthermore, a teaching tool such as comedic Theoretical Theatre, where teachers "portray characters who physically embody different theories in interactive scenarios including a Question Time-style debate, a chat-show, or a date", has been analysed as a case study and researchers have suggested that it could help ground theoretical material in the classroom compared to traditional lectures (Gravey et al. 2017). Similarly, comedy can improve student performance by attracting and holding a learner's attention, thus encouraging continued motivation and participation throughout the rest of the class (Savage et al. 2017).

Incorporating comedy in the classroom to add entertainment value has also been shown to make learning materials more memorable, so long as it is relevant and not so abundant that it is distracting (Gibb 2007). Similarly, in educational environments, music lyrics and songs have been shown to enhance vocabulary and comprehension, and to encourage creative thinking, particularly with comedy assignments such as incorporating song parodies to learn the English language (Boothe \& West 2015). Considering both comedy and music's connection with educational benefits in memory retention, learning, and recall, as well as both outlets' history of anti-authority and rebellious mentalities, informative comedic music appears to be an avenue for artists wanting to inform and entertain audiences at the same time. Because of these benefits, and the opportunity to create classroom discussions based off of the issues addressed, teachers may want to consider bringing informative comedy music into the classroom. However, with such an unexplored area of comedy and humour studies, selecting the appropriate content may be challenging. For the purposes of this study, a brief history of comedy music will be discussed next, leading to the work of comedy musician "Weird Al" Yankovic, as his songs predominantly focus on cultural commentary in the United States. This geographic limit will be an important factor, as the researcher will compare Yankovic's informative comedy music topics with the 
issues that U.S. citizens rate as the most important according to Pew Research polls, as well as with education standards set throughout the United States in 2010, referred to as the Common Core State Standards Initiative.

\subsection{Comedy music's history leading to "Weird Al" Yankovic}

Looking at the history of artists in comedic or novelty music also shows similar trends of informing while entertaining. Comedic music's history can be traced back to troubadours, wandering minstrels, and court jesters criticizing culture and the elite of the time ("Troubadour" 2009; Playing the fool" 2008; Otto 2007), transitioning through vaudeville acts filled with musical performances ("Vaudeville history" 2008), and continuing to the 1950s and 1960s when radio stations played the Top 40 hits that regularly contained novelty and comedy songs (Thompson 2013). Musicians such as Allan Sherman, Tom Lehrer, Spike Jones, and Stan Freberg were successful, often making social commentary through musical comedy leading into the 1970s (Saperstein 2015; Graves 2006), exemplified by Allan Sherman's album My Son, the Nut reaching number one on Billboard Top LPs chart in 1962 (Zolotow 1963). A portion of the comedy songs, much like civil rights and protest songs, aimed to advance society in a progressive sense and often used metaphor for greater impact (Trigg 2010). This is the case in Tom Lehrer's anti-war songs "We Will All Go Together When We Go", "Send the Marines", and "So Long, Mom (A Song for World War III)", among others (Hiltzik 2018).

In the 1970s, a major promotional effort for comedy music was made by radio host Barret Hansen, known as KPPC-FM's Dr. Demento, whose show focused on novelty, comedy, and musical oddities such as Frank Zappa ("The doctor is in" n.d.). The show launched a number of comedians' careers through its syndicated broadcast. Hansen's show was the first to play demos recorded by the 16-year-old "Weird Al" Yankovic, who would then go on to see decades of hits in popular music backed by a major record label with his own original funny songs as well as hit parodies such as turning Michael Jackson's "Beat It" into "Eat It", Coolio's "Gangsta's Paradise" into "Amish Paradise" and Chamillionaire's "Ridin' Dirty" into "White and Nerdy" (Rabin 2012). Though Yankovic's style still remains a subset of the music industry, his 14th album, Mandatory Fun, became the only comedy album to hit Number One on the Billboard Charts since Alan Sherman in 1963 (Caulfield 2014), carrying the comedic torch of those who came before him with songs containing dissident opinions, social commentary, and informative comedy. With a career spanning decades, Yankovic's works provide an analysis opportunity to explore comedy music as an informational tool regarding societal issues in the United States, scientific content, and grammar usage.

\section{Method}

Over the course of one week, the researcher listened to Yankovic's 15-album box set titled Squeeze Box, released in 2017, that included Yankovic's work spanning from the 1980s to 2017. Using the same issues and labels created by Pew Research when determining top issues for voters in the United States, the researcher coded all of Yankovic's songs if they addressed any of the top five Pew issues: the Economy, Terrorism, Foreign Policy, Health Care, and Gun Policy ("Top voting issues" 2016). The researcher also noted the precise time in each song when a reference to an issue occurred, so that sample lyrics could be located for repeat analysis later. 
Ludwig's critical practice text-analysing literacy resource (2003), a tool based on the works of Freebody \& Luke (1990), Freebody, Ludwig, \& Gunn (1995), and Luke \& Freebody (1999), was then used to examine the issues that Yankovic covered most frequently. This particular literacy resource was chosen as an analytical framework as it can help students interact with texts to become more functionally literate and "move beyond decoding and encoding print to understanding and using texts on several levels for a variety of purposes in a range of technologies" (Ludwig 2003). This adapted text-analysing literacy resource is available in Table 1 below and will be referred to throughout the results section.

Table 1. Ludwig's critical practice text-analysing literacy resource

\section{What does this text do to me?}

The emphasis is on understanding that written, spoken, visual, and multimodal texts are not neutral but represent particular points of view and silence others. This analysis includes:

- (A) recognising the writer, speaker, or shaper's purpose in creating a text and that texts influence people's ideas.

- (B) recognising opinions, bias, points of view, gaps, and silences and dominant readings in a text.

- (C) understanding how texts are crafted according to the values, views, and interests of the writer, speaker, or shaper.

- (D) identifying the ways in which information or ideas are expressed and represented to influence and position readers, viewers, or listeners.

- (E) presenting an alternative position to the one taken by a text or deciding to endorse the position taken by a text.

For the second part of the analysis regarding informative topics, the researcher also coded each song into the K-12 Common Core Standards areas of Math, Science, or English Arts and Literacy (Common Core State standards, 2018). Though Yankovic has a multigenerational audience, he has said that there is a large portion of his fanbase that tends to discover his work during their teenage years (Rabin 2012) and therefore these Common Core standard topic breakdowns are fitting with that demographic. By highlighting the educational areas that Yankovic's songs cover, this data will allow the researcher to discuss not only the potential informative comedy included in the songs, but also the possible related cultural issues that could come about through a critical literacy analysis in the classroom. Ludwig's Critical Practice textanalysing literacy resource (2003) was then used to examine the informative areas that Yankovic covered most.

\section{Results}

The most recurring cultural commentary issue addressed throughout "Weird Al" Yankovic's works was the U.S. economy, looked at from the perspective of characters of different financial statuses. Yankovic also brings science and English language educational topics to the listeners' attention far more than math. Both of these areas, cultural commentary of the economy and 
informative comedy regarding science and the English language arts, will be addressed in detail below with a breakdown of the number of instances.

\subsection{Addressing issues through cultural commentary}

Yankovic's most covered issue, using labels created by the Pew Research Poll, was the economy, with 18 songs featuring either direct mention of the economy or related issues such as income struggles. The second most frequent issue was foreign policy with five songs addressing war. Health care and gun policies were both addressed with two songs each, while terrorism was not addressed in any of Yankovic's work. Results of this coding are shown in Table 2, displaying the number of songs addressing each issue on all of Yankovic's albums.

Table 2. Album title issue breakdown

\begin{tabular}{|c|c|c|c|c|c|}
\hline \multirow[t]{2}{*}{ Album Title } & \multicolumn{5}{|c|}{ Issue (Pew Research) } \\
\hline & Economy & Terrorism & Foreign Policy & Health Care & Gun Policy \\
\hline Self Titled & 4 & 0 & 2 & 0 & 0 \\
\hline In 3-D & 2 & 0 & 0 & 0 & 0 \\
\hline Dare to Be Stupid & 1 & 0 & 0 & 0 & 0 \\
\hline Polka Party & 1 & 0 & 1 & 1 & 0 \\
\hline Even Worse & 1 & 0 & 0 & 0 & 0 \\
\hline UHF Soundtrack & 1 & 0 & 0 & 0 & 0 \\
\hline Off the Deep End & 0 & 0 & 0 & 0 & 1 \\
\hline Alapalooza & 1 & 0 & 0 & 0 & 0 \\
\hline Bad Hair Day & 1 & 0 & 0 & 0 & 0 \\
\hline Running With Scissors & 0 & 0 & 0 & 0 & 0 \\
\hline Poodle Hat & 0 & 0 & 0 & 0 & 0 \\
\hline Straight Outta Lynwood & 0 & 0 & 1 & 1 & 1 \\
\hline Alpocalypse & 3 & 0 & 1 & 0 & 0 \\
\hline Mandatory Fun & 2 & 0 & 0 & 0 & 0 \\
\hline Medium Rarities & 1 & 0 & 0 & 0 & 0 \\
\hline (Total) & 18 & $\mathbf{0}$ & 5 & 2 & 2 \\
\hline
\end{tabular}

Using Ludwig's critical practice text-analysizing literacy resource as seen in Table 1, the researcher analysed selected song samples with a critical approach that could be used in classroom settings to encourage learning by using Yankovic's work as supplemental materials. Such an analysis regarding the context of the songs' production, consumption, and interpretation will provide insight into the potential lessons or teaching moments using these songs in a classroom setting could provide. Ultimately, such an approach could assist learners in developing a critical stance towards these songs and the issues they discuss. The first song sample analysed, representing the economy issue, was Yankovic's 2011 rap song "Whatever You Like":

Hey, girl. You know our economy's in the toilet, but I'm still gonna treat you right / And you can always ride the city bus / Got a stack of tokens just for us / Yo, my wallet's fat and full of ones / Yeah, it's all about the Washingtons / That's right. You want White Castle? Need White Castle? / Long as you got me it won't be no hassle / You want it, we'll get it, just don't be a hater / If I grab a 
bunch of napkins for later / Thrift store jeans, on sale half price / The underwear at Goodwill is nice / And baby you can have whatever you like.

(Yankovic 2011a).

Sociocultural lessons about the United States can be created using Ludwig's critical practice literacy resource with the song "Whatever You Like". Looking at the first area of Ludwig's resource, section A, one must consider the writer's purpose in creating the text. As with all of Yankovic's songs, the purpose is to make audiences laugh. A second goal is to offer cultural criticism, as Yankovic discussed in an interview regarding how he sees his role as a modern-day court jester where he attempts to "prick the bubble of pretentiousness that sometimes pervades the industry... I'm a pop culture Cuisinart. I am providing cultural commentary" (Rivera \& Dubensky 2017). For section B in Table 1 (recognising points of view or bias in the text), the viewpoint of the character Yankovic included in the song must be considered when singing about the economy. This character, trying to win over the respect of a potential love interest, sings of a thrifty lifestyle in a genre of music usually reserved for arrogant claims about financial success such as "brag rap". Thus, the viewpoint of "Whatever You Like" comes from a poor character who must worry about saving money whenever possible.

A gap in the text would be the values and views expressed in the song Yankovic is parodying, also titled "Whatever You Like", but discussing the extravagant advantages of dating a singer who is wealthy and can treat his love to any of her desires. As Yankovic grew up in white middle-class suburbia in California, his struggles and upbringing could bias what is perceived as financial struggles. This corresponds to section $\mathrm{C}$ in Table 1 (Rabin 2012). The economy issue addressed in this song is never presented with a judgmental outlook on the wealthy class above the singer, but is likely trying to display the hardships that many citizens go through who are not financially independent. This corresponds to section $\mathrm{D}$ in Table 1, where one must identify the ways in which information or ideas are expressed to influence the listeners. Finally, considering the alternative position to the one represented in the song (section E), an educator could ask students to consider their own socioeconomic status and compare their unique backgrounds with the perspective of the singer. An educator could also ask how a song in the "brag rap" genre would be received by different groups if it broke conventions and sang of financial hardships and how that has had a negative impact on their pursuits of basic necessities.

In "Whatever You Like", instead of showing off sports cars and Benjamins - 100-dollar bills - the character proudly discusses his collection of one-dollar bills and bus tokens. There are no promises of a future life of luxury, nor any unrealistic promises made by the character to his potential mate. The message is to make the best of what one has, and to sometimes accept the cards that have been dealt. This message can be discussed with students in relation to why voters in the United States view the economy as an important issue. On the same album, Yankovic writes from the perspective of another character using haggling tactics for beneficial deals on the website Craigslist, showing a similar mindset of frugality: "You've got a 65 Chevy Malibu / With automatic drive, a custom paint job too / I'll trade you for my old wheelbarrow / And a slightly-used sombrero / And I'll even throw in a stapler, if you insist / Craigslist! I'm on Craigslist, baby, come on" (Yankovic 2011b).

Educators desiring to create conversations in the classroom and have students critically analyse texts could compare the way "Craigslist" and "Whatever You Like" discuss the economy and how those with an Internet connection in "Craigslist" seem to be more financially privileged than the characters in "Whatever You Like". Access to technology could also be brought into the 
discussion, addressing additional power struggles. The concept of frugality can also be seen in a parody of Pharrell Williams' summer phenomenon "Happy", featuring a bouncing beat and infectious handclapping, about living a cheerful life. Yankovic morphs the original song into a self-laudatory tune about being tacky, many aspects of such a dubious attribute involving pennypinching: " 43 bumper stickers and a YOLO license plate / Bring along my coupon book whenever I'm on a date / Practice my twerking moves in line at the DMV / Took the whole bowl of restaurant mints. Hey, it said they're free" (Yankovic 2014a).

Nearly every statement made in "Tacky" involves a character embarking on a potentially embarrassing situation, yet in this case, fully embracing it with no shame. Throwing off the pressures of caring about what other people think is an underlying message, as well as feeling better about oneself should they ever violate a mainstream cultural taboo. It could lead to students discussing what actions they view as tacky and how their own sociocultural backgrounds could influence that opinion. Comparing Yankovic's middle-class upbringing with their own, whatever that may be, could lead to introspective moments. Yankovic's songs also capture the everyday experience of working for a living rather than for fulfillment. Such songs are particularly relevant, as Millennial audiences are now aging in an uncertain job market and are more likely to stick with one employer rather than of continuing to switch careers (Deloitte 2017). Yankovic's earliest song on unfulfilling jobs, "Dog Eat Dog", captures the office job environment much like the film Office Space in 1999 or the television program The Drew Carey Show that aired from 1995 to 2004 on U.S. television. Though this time, Yankovic writes from the perspective of somebody who loves the banalities of the work-a-day world in the style of the musical group Talking Heads:

Found a job in a great big office / And I really love this place / I got my, my very own scotch tape dispenser / And I've got a private parking space. Ha! / And I, I got my coffee mug with my, with my name right on it / In big bold letters, so everyone knows it's mine / Don't even touch it 'cause, 'cause it doesn't belong to you / And I'm watchin' you, so don't get funny / I'm climbing up, up the corporate ladder / Watch out! It's dog eat dog.

(Yankovic, 1986a).

"Dog Eat Dog" provides another opportunity to address sociocultural issues about the United States using Ludwig's critical practice literacy resource. Analysing this song according to section A in Ludwig's critical practice literacy resource in Table 1, the goal is likely to make people laugh through the banality of everyday desk jobs. Using section B, judging the opinion of the writer, the worker enjoys his cubicle and stable job despite some of the work-related drama. Much like "Tacky", many of Yankovic's character's perceived judgments can be compared and contrasted, asking if the characters in those songs seem to come from different backgrounds. In section $\mathrm{C}$ of the literacy resource (judging the values and views of the writer), further insight can be gained from an interview with Yankovic where he stated that his inspiration for "Dog Eat Dog" came from his life before fame, when he worked his way up from the mailroom to the office at the radio syndication company Westwood One. In this interview, Yankovic said "At first I thought it was kinda cool that I had a phone and a desk and a little cubicle to call my own, but after a while I felt like my soul had been sucked out of me. The song is kind of a tongue-incheek look at office life" (Yankovic 1994). Using section D of Ludwig's literacy resource (the ways the information is expressed to persuade the listener), Yankovic reveals many of the small details of office life as viewed as major points of celebration, again juxtaposing ideas that would 
not typically be glorified in song. Educators using this song as supplementary materials could ask the question if the character is legitimately excited about work or if he has forced himself to find joy in the small details because he is required to work and make money. Finally, the alternative position being considered in section E could be somebody who is miserable at their job and is dissatisfied with their career path. This would naturally lead to educators having students consider their own potential career goals and asking them to take actions that will allow them to find employment as enjoyable as Yankovic's character does.

Similarly, Yankovic would go on to write another song from the perspective of an employee stuck in his career path, this time about an actor forced to waste his talent working at a Disney Park attraction. This song, "Skipper Dan", can also be critically analysed and compared with "Dog Eat Dog", especially considering that it is one of Yankovic's darker songs about a character unhappy with his employment. Students listening to this song sample could first be told that Yankovic got the idea while riding the Jungle Cruise ride with his family when the skipper tour guide made a joke about his failed acting career amidst the scripted tourist-targeted material, leading to this bittersweet tale:

Oh, the critics, they used to say / I was the new Olivier / Thought I'd be the toast of Sundance or maybe Cannes / Aw, but don't bother tryin' to IMDB me / The only place you might possibly see me / Is ridin' my little boat around Adventureland / It ain't exactly what I planned / But I'm a tour guide on the Jungle Cruise ride / Skipper Dan is the name / And I'm doin' 34 shows every day / And every time it's the same / I would've killed if I'd been in Speed the Plow / But what's the difference? That's all behind me now / Cause I'm payin' the rent and I'm swallowin' my pride / And I'm workin' on the Jungle Cruise ride.

(Yankovic 2011c).

This song aims to address other sub-issues that fall under the economy, such as thankless employment, representing a portion of society who may not find their careers to be rewarding. Yankovic shared his connection to the song in an interview where he described how he could relate to people like the skipper he met on the ride: "I kind of related in a way because I do the same show, more or less, every night, but to do the same shtick literally several dozen times a day - I would think that would probably wear on you" (Inside the Magic 2010). Comparing the perspective of the character in "Skipper Dan", who was able to go to college and hone his acting craft, with the character from "Whatever You Like", who seems to bounce from job to job, could create discussion regarding represented voices and what information is reinforced that students already know about the importance of hard work and pursuing one's dreams.

Yankovic's song "Alimony" is another commentary on life struggles related to money, focusing on the loss of love and assets after a failed marriage. This song uses Yankovic's comedic juxtaposition technique - "the placement of two or more things side by side, often in order to bring out their differences" ("Juxtaposition" 2015) - as a sad and broken man sings to the drum-driven rock song with cheering crowds featured in the background. Such aesthetic choices offer a different take on the typically confident rock genre: "Here she comes now, wants her alimony / Bleedin' me dry as a bony bony / Workin' three jobs just to stay in debt now / Well, first she took my nest egg then she took the nest" (Yankovic 1988a). 


\subsection{Informing audiences about science and English language arts}

Yankovic's most addressed informational topic, using the labels created for Common Core educational standards, is science, with a total of seven songs. The second most occurring informational topic is English language arts, with a total of three songs, while math had zero. Results of this coding are shown in Table 3, displaying the number of songs covering each informational topic on all of Yankovic's albums.

Table 3. Album title information topic breakdown

\begin{tabular}{|l|r|r|r|}
\hline \multirow{2}{*}{ Album Title } & \multicolumn{3}{|c|}{ Information Topic } \\
\cline { 2 - 4 } & Math & Science & English Language Arts \\
\hline Self Titled & 0 & 0 & 0 \\
\hline In 3-D & 0 & 0 & 0 \\
\hline Dare to Be Stupid & 0 & 1 & 0 \\
\hline Polka Party & 0 & 0 & 0 \\
\hline Even Worse & 0 & 1 & 0 \\
\hline UHF Soundtrack & 0 & 0 & 0 \\
\hline Off the Deep End & 0 & 0 & 0 \\
\hline Alapalooza & 0 & 0 & 0 \\
\hline Bad Hair Day & 0 & 0 & 0 \\
\hline Running With Scissors & 0 & 0 & 0 \\
\hline Poodle Hat & 0 & 1 & 0 \\
\hline Straight Outta Lynwood & 0 & 1 & 1 \\
\hline Alpocalypse & 0 & 1 & 0 \\
\hline Mandatory Fun & 0 & 0 & 2 \\
\hline Medium Rarities & 0 & 1 & 0 \\
\hline & & 1 & 3 \\
\hline
\end{tabular}

Ludwig's critical practice literacy resource can also be applied to sample song lyrics as a form of critical language analysis, which Fairclough defines as a "conscious attention to properties of language and language use as an element of language education" (Fairclough 1992). In this regard, analysing Yankovic's works will provide insight into science and the English language arts and related cultural issues such as the economy. They will also go an additional step in potential instruction as they include scientific explanations of topics and grammar rules. One of Yankovic's early science related songs, a parody of "I Think We're Alone Now" titled "I Think I'm A Clone Now", where Yankovic explains scientific concepts and touches on medical topics while working complex terminology into informative comedic music, will now be analyzed with a critical literacy approach:

Part of some geneticist's plan / Born to be a carbon copy man / There in a petri dish late one night / They took a donor's body cell and fertilized a human egg and so I say / I think I'm a clone now / There's always two of me just a-hangin' around / I think I'm a clone now / 'Cause every chromosome is a hand-me-down.

(Yankovic 1988b). 
Much like a multicultural classroom setting where students are exposed to other languages through language awareness tools, students can be exposed to scientific terms and concepts by using such informative comedy songs in the classroom. Looking at the first area of Ludwig's critical practice literary resource, section A, the likely goal of this song is to generate laughter by working in complex scientific terms into a parody of a romantic pop song. In the past, Yankovic has said that he had always enjoyed math and science and a number of his songs are miniature doctoral dissertations describing intricate scientific concepts (Rabin 2012). This information about Yankovic fits within sections B and C of Ludwig's critical practice literacy resource, as the opinions and values of the writer can lead to classroom discussion and the ability to analyse the intent of media texts. At face value, the song about cloning provides an educational opportunity in a classroom setting regarding biology and genomics that could then be reinforced or explained by a teacher in a relevant classroom, but there are also other issues that can be addressed in the classroom that will be discussed below.

Taking into consideration Yankovic's pro-science background and the enthusiastic perspective of the character in the song, educators could initiate a discourse regarding section $\mathrm{D}$, identifying the ways that the writer is expressing himself and trying to influence potential listeners. Educators incorporating this song into the classroom could discuss the background of the character and the impact of an enthusiastic positive delivery on listeners. Finally, in section E of Ludwig's critical practice text-analysing literacy resource, one must consider an alternative position to the one taken in the text, which, in this case, could involve discussion about a character uninterested in science. Questions such as why the character may not be interested in biology and what arguments could be made to convince the character that science is important could be asked, which may become increasingly important as anti-science movements are able to spread quickly through the Internet, with the number of Flat Earth theorists recently increasing in the United States, for example (Drake 2017).

Through the use of wordplay and puns, Yankovic is able to convey genetics concepts that would normally belong in a textbook or a classroom lecture, and that are potentially made more memorable through a beat and rhyme scheme. It is important to note that "I Think I'm a Clone Now" was released in 1988, before U.S. media heavily covered stories that popularized related terminology such as Dolly the Sheep in the mid-1990s (Weintraub 2016; Zurek 2000). Like Frank Zappa, one of his idols, Yankovic covers a variety of topics in a genre-crossing style, and is known for sneaking critiques and lessons into music. Continuing with scientific and medical processes, Yankovic has also described hernias in his 1986 James Brown parody of "Living in America" titled "Living with a Hernia", and provided two detailed explanations of the inner workings of the human pancreas and brain in his originals "Pancreas" and "The Brain Song". All three are shown below:

You may not be familiar with the common types of hernias that you could get / So just settle down, let me clue you in / There's incomplete, epigastric, bladder, strangulated, lumbar hernia, Richter's hernia, obstructed, inguinal, and direct

(Yankovic 1986b).

Flow, flow, flow, pancreatic juice / Flow, flow, into the duodenum / Insulin, glucagon / Comin' from the islets of Langerhans / Lipase, amylase, and trypsin / They gonna help with our digestion

(Yankovic 2006b). 
Your brain is divided into two hemispheres / Your left controls your right side and your right controls your left side / And they're both tied together in a neat little package / By the totally awesome Corpus Callosum / When you peel away that meninges layer / Wipe off that cerebro-spinal fluid / And you're looking right at the four lobes of the brain / Frontal, temporal, parietal, occipital.

(Yankovic 2017)

In all three songs, Yankovic lays out not only a series of terms, but also explains their functions in musical earworms, managing to convey biology lessons in a matter of minutes. Such tactics have also been executed by informative comedic music acts in the past, going back to Tom Lehrer's "The Elements" song containing 102 elements of the Periodic Table delivered at a swift rate and leading up to Bill Nye the Science Guy and Animaniacs in the 1990s. Much like how children may learn their alphabet with the "ABC" song, Yankovic and other informative comedy artists have the power to provide the rhyming scheme and patterns to assist learners in memorizing long lists and intricate processes (Smith 2000). Should educators embrace these songs as supplementary materials, the understandings and discourse that can come later in Bloom's Taxonomy such as evaluation and synthesizing may come easier or at a quicker pace, with lower levels, such as comprehension, assisted by these informative comedy examples.

Continuing with the analysis, the second most occurring information topic was English language arts, with grammar tips worked into the lyrics. Two of these potential learning moments occurred on Yankovic's 2014 album Mandatory Fun. The first one, titled "Word Crimes", is a parody of Robin Thicke's controversial tune "Blurred Lines":

One thing I ask of you / Time to learn your homophones is past due / Learn to diagram a sentence too / Always say 'to whom' / Don't ever say 'to who' / And listen up when I tell you this / I hope you never use quotation marks for emphasis / You finished second grade. I hope you can tell / If you're doing good or doing well / You'd better figure out the difference / Irony is not coincidence / And I thought that you'd gotten it through your skull / What's figurative and what's literal / Oh but, just now, you said you literally couldn't get out of bed / That really makes me want to literally smack a crowbar upside your stupid head.

(Yankovic 2014b).

Using the first area of Ludwig's critical practice literacy resource, section A, the writer's purpose is likely to entertain with the juxtaposition of putting a topic such as grammar lessons into a parody of a pop song about sexual solicitation. In a 2017 interview, Yankovic said that the song is not designed as classroom curriculum, but that it is supposed to make fun of people who do not care about grammar because bad grammar irritates him (Fox 2017). This provides an educational opportunity for students taking a critical literacy analysis approach looking at not only the grammar, but also the point of view of the writer in section B of Table 1. Taking Yankovic's background into consideration - he has had a passion for language at an early age and graduated from high school at age 16 as a valedictorian (Hiskey 2011) - can also be a part of section B, the perspectives of the writer and the media text. Gaps in the media text perspective, section $\mathrm{C}$, involve people who do not have a grasp on grammar, perhaps due to their upbringing, the quality of their teachers, or access to education. Moving on to section D in Ludwig's critical practice literacy resource (identifying the ways the information is expressed), it is helpful to understand the text, as the song is written from the perspective of somebody who is angry about bad grammar. Discussing why such feelings can come about from grammar mistakes, and how the increase of service sector jobs in the United States has changed communication expectations, 
could be beneficial to a classroom. Fairclough discusses these service sector changes as a "largescale restructuring of employment" (Fairclough 1992). The alternative position, section E, could be a character singing about living a carefree life without making grammatical considerations and how that could affect their lives.

English language arts lessons conveyed through song containing comedic elements have also been popularized through other media such as Schoolhouse Rock in the 1970s with such grammar songs as "A Noun is a Person, Place, or Thing", "Verb: That's What's Happenin'," "Conjunction Junction", "Interjections!" and "Busy Prepositions". Sesame Street aimed to inform viewers with parody songs in the 1980s such as "Letter B", a parody of The Beatles' "Let It Be". Continuing with Yankovic's music, in the original song "Close but No Cigar", a grammar issue becomes the breaking point for one of his characters when a quest for love is ruined by a mistake:

Jillian was her name / She was sweeter than aspartame / Her kisses reconfigured my DNA / And after that I never was the same / And I loved her even more than Marlon Brando loved soufflé / She was gorgeous, she was charming, yeah, she was perfect in every way / Except she was always using the word infer when she obviously meant imply / And I know some guys would put up with that kind of thing, but frankly, I can't imagine why.

(Yankovic 2006a).

Yankovic's intent in "Close but No Cigar" is to show the ludicrousness of a man finding small quirks or minor issues with potential mates who are otherwise impeccable matches for him, yet the facetiously educational moment still stands. Should educators embrace these songs as supplementary materials, basic grammar rules that typically require route memorization could be taught to students in entertaining ways and used as launching points for a deeper understanding of the material in the context of U.S. culture.

\section{Conclusion}

The exploratory critical language analysis techniques used in this study show the potential for informative comedy's classroom inclusion as a means to address issues through cultural commentary and encourage education regarding science as well as the English language. Using critical analysis tools such as Ludwig's critical practice literacy resource, educators may be able to incorporate informative comedy with a learner-centric pedagogy, allowing students to ask questions and bring in their own perspectives, interests, and backgrounds to create a discourse in the classroom. More possibilities and connections to research will now be discussed.

\subsection{Addressing serious issues through cultural commentary}

Since music is part of students' daily social routine, and humour is prevalent in online video and memes, incorporating informative comedy music such as "Weird Al" Yankovic's may provide a unique opportunity to create memorable learning moments through cultural commentary, perhaps even more than with non-comedic songs. Research has found that the promotion of good times in social settings with parties and substance abuse (Primack et al. 2008) and lost or celebrated love (Knobloch et al. 2004) or finding potential romantic partners (Carpentier et al. 
2007) were common themes in popular music. Other sub-genres such as "brag rap" have also been analysed, revealing vain values of sexual prowess and celebration of wealth (MartinezMorales 2015). Conversely, informative comedy musicians such as "Weird Al" Yankovic are more likely to incorporate everyday existence - not just the lifestyles of the wealthy and famous - into the mix. In this sense, Yankovic's informative comedy music provides an airing of the woes of middle and low-class America and the disaffected as their views and relatable serious issues are sometimes not otherwise represented in media. Students are able to analyse his works looking for power relationships and to uncover such underlying messages.

As the results show, the most frequent issue addressed in Yankovic's social commentary is the economy, fitting with the United States 2016 potential voter Pew Research poll where the economy was rated as the top issue when choosing a President ("Top voting issues" 2016). By including Yankovic's songs into the classroom and analysing them from a critical literacy approach, educators could create a number of comparisons between texts. Yankovic's parody "Whatever You Like", which focuses on a less financially fortunate character, can be compared and contrasted with the original song's rich character who had seemingly limitless amounts of money. Or, by playing multiple examples from Yankovic's works analysed in this paper, educators could encourage a comparison of perspectives and an interpretation of values and attitudes in the works of the same artist. Educators would be able to analyse how the poor in "Whatever You Like", the middle class in "Dog Eat Dog", and a person early in his career in "Skipper Dan" relate to the economy in the United States.

In a number of Yankovic's songs, the characters often sing of frugality, paying rent, and unfulfilling career pursuits. By singing about such struggles using upbeat, generally joyful music, he attempts to instill a sense of empathy as well as potentially get laughs from listeners, knowing that a performer understands their hardships, all of which can be discussed in a classroom setting. In Yankovic's work, worries about money and bouts of inventive frugality abound, and the working and middle classes can share a laugh much like Allan Sherman's audience with his inside jokes to the Jewish community as well as those in suburban communities. Yankovic's early career included multiple songs about food and monetary concerns. Yankovic has commented on his days as a struggling artist, when food was a major concern ("First job" 2016). Such perspectives included in these informative comedic songs can be analysed from a critical literacy perspective to encourage classroom discussion and analyse the writer's bias, when and how the works were produced, how the works are consumed by others, and what pertinent issues are addressed in the society where the songs have been crafted.

\subsection{Informing audiences about science and English language arts}

With the proliferation of music streaming and online song intake, adding informative comedy music to the classroom as a part of learning materials can modernize the classroom by helping to adapt to the students' interests, allowing educators to incorporate Ludwig's critical practice literacy resource as a tool to encourage independent thought and expression. As the results show, Yankovic crafted most of his informative comedy songs about science, with the second most informative topic being the English language arts. Again, linked to previous research, these informative comedy songs may provide an extra opportunity for learning as compared to traditional pop music. As Morris explains in an example (2017), popular music can sometimes feature repetitive words that would not lead to much opportunity for teaching more advanced concepts. However, the informative comedy songs of "Weird Al" Yankovic that explained 
complex scientific processes and biological functions, for example, contrast with pop music that features repetitive words as found in previous research using the Lempel-Ziv algorithm to analyse the number of unique words used in each song (Morris 2017). This algorithm, usually used in data compression to substitute repeated segments of data, has been applied to music by analysing and compressing an entire song's lyrics by looking for repeated sequences and repetitive words. The Lempel-Ziv algorithm applied to songs then provides a percent of repetitiveness that can be compared to another song's percent (Morris 2017).

Regarding grammar, informative comedy music songs such as "Weird Al" Yankovic's "Word Crimes" may allow educators to take the classroom discussion far beyond basic grammar lessons. For example, when Yankovic's character in "Word Crimes" demands that people speak in proper English, it brings about more potential teachable moments such as the privilege that native speakers have when interacting with non-native speakers. As English linguist Squires suggests (2014), comedy videos and songs used in education can convey "valuable linguistic lessons... but not without a teacher encouraging students to think beyond the video itself" (Squires 2014). Using examples such as Yankovic's, compared with his parody targets that may have more repetitive words, would allow students to analyse each artist's vocabulary or character in their songs, ask questions about their possible sociocultural statuses, and assist in the learning process in a similar fashion to the educational songs featured on children television shows or online instructional modules. Also considering the ways in which people are interacting online, with the spread of fake news containing questionable anti-science stances such as the repopularization of the Flat Earth theory, these songs could create a dialogue to discuss not only the science, but also why these ideologies may be increasing. Similarly, younger generations showing less concern for spelling and grammar as their online interactions increase, may lead to a variety of conversations in the classroom as to how one's upbringing or access to technology can affect their ability to express themselves.

Considering comedy's history of critiquing society, as well as the positive effects it can have on information recall, enhancing vocabulary, and explaining complex material in palatable ways for audiences as discussed in the literature, incorporating such tactics into the classroom using informative comedy music could become an effective means to enlighten audiences in entertaining ways. Such music could also lead students to act upon these messages and change perceived unfair structures, which is one of the end goals of a critical literacy approach (Shor 1999). "Weird Al" Yankovic's music catalogue shows the potential to address serious issues in the United States, much like the pop genre in which he creates content. Such issues may have the potential to become more memorable through comedy and the direct guidance of an instructor with a critical literacy approach. Vocabulary lessons and scientific explanations could see the same benefit in educational content expressed via informative comedic song, questioning the underlying hierarchies that create prejudices regarding the ways people communicate.

\subsection{Limitations and future research suggestions}

As this is an exploratory study, no statistical analysis was performed or pretest-posttest design was implemented to show the effects of using informative comedy in the classroom. Future studies could be performed in this area to test any effect including informative comedy songs in the classroom could have, adding knowledge to a relatively unexplored topic. Also, the only informative comedy songs analysed in this study were those of "Weird Al" Yankovic, as the researcher wanted to focus on issues important to United States citizens and connect those with a 
singer originating from the same country to shape a targeted critical analysis. However, with the proliferation of the Internet and user-generated content creators uploading funny songs around the world, future research could also be conducted on comedy singers in other parts of the world such as Psy from South Korea, Ylvis from Norway, and Flight of the Conchords from New Zealand.

Another limitation involves the careful balance an educator must strike when combining humour with educational content. The optimal amount of humour activities in a classroom was found to be three to four per lesson, when in previous research, two separate sections of a class were taught by the same professor and the humour group outperformed the nonhumour group's final exam score by 10 percent (Ziv 1981). These results were then replicated by another teacher with different groups covering another subject (Ziv 1988). Similarly, while comedic and emotional scenes in media content can release noradrenaline in the limbic system of the brain that assists with memory (Southwick et al. 2002), excessive amounts of humour in educational material has been shown to lead audiences to believe that the issues are less serious in some cases (Moyer-Gusé et al. 2011). Some authors also argue that, when comedy with political comedy or educational content becomes too mean-spirited, its inflammatory and reactionary nature reduces effectiveness. This last factor, mean-spirited comedy potentially having a negative impact on education effectiveness, also led the researcher to solely examine the works of Yankovic, as he has discussed his family-friendly persona (Berkowitz 2012) and how he avoids blue or offensive content for the greatest comedic effect (Rabin 2012).

\section{References}

Berkowitz, J. (2012). 'Master class: "Weird Al" Yankovic on how to make a great parody'. Retrieved from https://www.fastcompany.com/1681833/master-class-weird-al-yankovic-onhow-to-make-a-great-parody

Boothe, D., \& West J. (2015). 'English language learning through music and song lyrics: The performances of a lifetime'. Proceedings of The Future of Education Conference, Florence, Italy: Pixel, pp. 248-254.

Brassett, J. (2016). 'British comedy, global resistance: Russell Brand, Charlie Brooker and Stewart Lee'. European Journal of International Relations 22, pp. 168-191. https://doi.org/10.1177/1354066115586816

Brewer, P. R., \& Marquardt, E. (2007). 'Mock news and democracy: Analyzing The Daily Show'. Atlantic Journal of Communication 15, pp. 249-267. https://doi.org/10.1080/15456870701465315

Carpentier, F. D., Knobloch-Westerwick, S., \& Blumhoff, A. (2007). 'Naughty versus nice: Suggestive pop music influences on perceptions of potential romantic partners'. Media Psychology 9 (1), pp. 1-17. https://doi.org/10.1080/15213260709336800

Caulfield, K. (2014). 'Weird Al Yankovic gets first no. 1 album on Billboard 200 with mandatory fun'. Retrieved from http:/www.billboard.com/articles/columns/chartbeat/6176745/weird- alyankovic-billboard-200-mandatory-fun-number-one

Chattoo, C., \& Feldman, L. (2017). 'Storytelling for social change: Leveraging documentary and comedy for public engagement in global poverty'. Journal of Communication 67 (5), pp. 678-701. doi:10.1111/jcom.12318

Common Core state standards (2018). Retrieved from http://www.corestandards.org/read-thestandards/ 
Deloitte. (2017). The Deloitte Millennial Survey 2017 [Data set]. Retrieved from https://www2.deloitte.com/global/en/pages/about-deloitte/articles/millennialsurvey.html

Dorian, L. (2016). 'Make America protest again: The year pop got political'. Retrieved from https://www.billboard.com/articles/events/year-in-music-2016/7616882/music-2016politics-beyonce-neil-young-protest

Drake, M. (2017). 'Did NASA lie? Flat Earth "conspiracy theory" growing thanks to celebrity endorsement'. Retrieved from https://www.express.co.uk/news/weird/891130/NASA-USAFlat-Earth-conspiracy-theory-Kyrie-Irving-BoB-Freddie-Flintoff-Mike-Hughes-news

Fairclough, N. (1992). Language and Power. London: Longman.

Feldman, L. (2007). 'The news about comedy: Young audiences, The Daily Show, and evolving notions of journalism'. Journalism $8 \quad$ (4), $\quad$ pp. $406-427$. https://doi.org/10.1177/1464884907078655

First job. (2016, May 4). Retrieved from http://teamcoco.com/video/-weird-al-yankovicaccordion-repo

Fox, J. (2017). "How "Weird Al" Yankovic removed the misogyny of "Blurred Lines" by adding grammar lessons'. Retrieved from http://www.vulture.com/2017/03/weird-al-on-wordcrimes-his-blurred-lines-parody.html

Freebody, P., Ludwig, C., \& Gunn, S. (1995). 'Everyday literacy practices in and out of schools in low socioeconomic urban communities'. Brisbane: Centre for Literacy Education Research, Griffith University.

Freebody, P. \& Luke, A. (1990). 'Literacies programs: Debates and demands in cultural context'. Prospect 5, pp. 7-16.

Gibb, B.J. (2007). The Rough Guide to the Brain. London: Penguin.

Graves, T. (2006). 'Rock \& Roll disc interview: Frank Zappa'. Retrieved from http://tomgraves.blogspot.com/2005/01/my-long-ass-interview-with-frank-zappa.html

Gravey, V., Lorenzoni, I., Seyfang, G., \& Hargreaves, T. (2017). 'Theatrical theatre: Harnessing the power of comedy to teach social science theory'. Journal of Contemporary European Research 13 (3), pp. 1319-1336.

Green, A., \& Linders, A. (2016). 'The impact of comedy on racial and ethnic discourse'. Social Inquiry 86 (2), pp. 241-269. doi:10.1111/soin.12112

Gunderson, L. (2006). 'Science plays come of age'. Retrieved from http://www.thescientist.com/?articles.view/articleNo/24219/title/Science-plays-come-of-age/

Hariman, R. (2008). 'Political parody and public culture'. Quarterly Journal of Speech 94 (3), pp. 247-272. https://doi.org/10.1080/00335630802210369

Hiskey, D. (2011). "Weird Al" Yankovic was the valedictorian of his class in high school'. Retrieved from http://www.todayifoundout.com/index.php/2011/02/weird-al-yankovic-wasthe-valedictorian-of-his-class-in-high-school/

Hiltzik, M. (2018). 'A few words wasted about Tom Lehrer on his 90th birthday'. Retrieved from http://www.latimes.com/business/hiltzik/la-fi-hiltzik-lehrer-20180409-story.html

[Inside the Magic]. (2010, July 23). 'Interview with Weird Al Yankovic about Skipper Dan' [Video File]. Retrieved from https://www.youtube.com/watch?v=xckPiNhY-Ek

Juxtaposition. (2015, June 1). Retrieved from https://literaryterms.net/juxtaposition/

Knobloch, S., Weisbach, K., \& Zillmann, D. (2004). 'Love lamentation in pop songs: Music for unhappy lovers?'. Zeitschrift für Medienpsychologie 16 (3), pp. 116-124. https://doi.org/10.1026/1617-6383.16.3.116. 
Ludwig, C. (2003). 'Making sense of literacy'. Newsletter of the Australian Literacy Educators' Association. Retrieved from https://www.alea.edu.au/documents/item/53

Luke, A. \& Freebody, P. (1999). 'Further notes on the four resources model', Reading Online.

Martinez-Morales, V. (2015) 'Damaged petals and tenacity: Values expressed in fourth generation rap'. Master's thesis. Retrieved from https://repository.asu.edu/attachments/164086/content/MartinezMorales_asu_0010N_15477. pdf

McCarron, K., \& Savin-Baden, M. (2008). 'Compering and comparing: Stand-up comedy and pedagogy. Innovations in Education and Teaching International 4 (4), pp. 355-363. https://doi.org/10.1080/14703290802377158

McDonald, J. (1988). 'Politics revisited: Metatextual implications of rock and roll criticism'. Youth \& Society 19 (4), pp. 485-504.

Morris, C. (2017). 'An exercise in language compression: Are pop lyrics getting more repetitive?'. Retrieved from https://pudding.cool/2017/05/song-repetition/

Moyer-Gusé, E., Mahood, C., \& Brookes, S. (2011). 'Entertainment-education in the context of humour: Effects on safer sex intentions and risk perceptions'. Health Communication 26 (8), 765-774. doi: 10.1080/10410236.2011.566832

Odysseos, L. (2001). 'Laughing matters: Peace, democracy and the challenge of the comic narrative'. Millennium 30 (3), pp. 709-732. https://doi.org/10.1177/03058298010300030501

Otto, B. (2007). Fools Are Everywhere: The Court Jester Around the World. Chicago: University of Chicago Press.

Pathmanathan, S. (2014). 'Learning science through humour in children's media'. International Studies in Humour 3 (1), pp. 94-107.

Pilcher, H. (2010). 'Communication: A better class of heckle'. Nature 467, pp. 530. doi:10.1038/467530a

Playing the fool. (2008, February). BBC History Magazine. Retrieved from http://www.annawhitelock.co.uk/wp-content/uploads/2011/07/Feb_Jesters_5dm.pdf

Primack, B. A., Dalton, M. A., Carroll, M. V., Agarwal, A. A., \& Fine, M. J. (2008). 'Content analysis of tobacco, alcohol, and other drugs in popular music'. Archives of Pediatrics \& Adolescent Medicine 162 (2), pp. 169-175. doi: 10.1001/archpediatrics.2007.27

Rabin, N. (2012). Weird Al: The Book. New York,: Abrams Books.

Rivera, D. \& Dubensky, J. (Series Producers). (2017, August 17). 'Making Fun'. [Television Program]. in The History of Comedy. CNN, GA: Hazy Mills Productions.

Saperstein, P. (2015). 'Comedian and voice actor Stan Freberg dies at 88'. Retrieved from http://variety.com/2015/tv/news/stan-freberg-comedian-satirist-dies-dead-1201467899/

Savage, B.M., Lujan H.L., Thipparthi R.R., \& DiCarlo S.E. (2017). 'Humor, laughter, learning, and health! A brief review'. Advances in Physiology Education 41, pp. 341-347. https://doi.org/10.1152/advan.00030.2017

Shor, I. (1999). 'What is critical literacy?'. Journal of Pedagogy, Pluralism, and Practice 4 (1), pp. 1-32.

Smith, J. (2000). 'Singing and songwriting support early literacy instruction'. Teaching Reading 53 (8), pp. 646-651.

Southwick, S., Davis, M., Horner, B., Cahill, L., Morgan, C.A., Bremner, J.D., \& Charney, D.C. (2002). 'Relationship of enhanced norepinephrine activity during memory consolidation to enhanced long-term memory in humans'. American Journal of Psychiatry 159 (8), pp. 14201422. https://doi.org/10.1176/appi.ajp.159.8.1420 
Squires, L. (2014). '25 Question for teaching with "Word Crimes". Retrieved from http://languagelog.ldc.upenn.edu/nll/?p=13521

The doctor is in. (n.d.). Retrieved from http://www.drdemento.com/dr-bio.html

Thompson, S. (2000). 'Tom Lehrer Interview'. Retrieved from http://www.avclub.com/article/tom-lehrer-13660

Thompson, S. (2013). 'Dr. Demento Interview'. Retrieved from http://www.avclub.com/drdemento-1798208198

Top voting issues. (2016, July 7). Retrieved from http://www.people-press.org/2016/07/07/4-topvoting-issues-in-2016-election/

Trigg, C. (2010) 'A change ain't gonna come: Sam Cooke and the protest song'. University of Toronto Quarterly 79 (3), pp. 991-1003. https://doi.org/10.3138/utq.79.3.991

Troubadour. (2009). in Encyclopedia Britannica. Retrieved from https://www.britannica.com/art/troubadour-lyric-artist

Vaudeville history. (2008, December 2). Retrieved from http://www.pbs.org/wnet/makeemlaugh/comedys-evolution/history-vaudeville-andbroadway/31/

Warner, B., Hawthorne, H., \& Hawthorne, J. (2015). 'A dual-processing approach to the effects of viewing political comedy'. Humor 28 (4), pp. 541-558. https://doi.org/10.1515/humor2015-0099

Weintraub, K. (2016). '20 years after Dolly the sheep led the way-Where is cloning now?" Retrieved from https:/www.scientificamerican.com/article/20-years-after-dolly-the- sheepled-the-way-where-is-cloning-now/

White, R. (2016). 'Funny peculiar: Lucille Ball and the vaudeville heritage of early American television comedy'. Social Semiotics $26 \quad$ (3), pp. 298-310. https://doi.org/10.1080/10350330.2015.1134826

Wood, P. (2015). 'Eternal protest: Bob Dylan's lasting rage'. Academic Questions 28, pp. 313321. https://doi.org/10.1007/s12129-015-9514-z

Yankovic, A. (1986a). 'Dog eat dog'. Polka Party [CD]. California: Scotti Brothers Records.

Yankovic, A. (1986b). 'Living with a hernia'. Polka Party [CD]. California: Scotti Brothers Records.

Yankovic, A. (1988a). 'Alimony'. Even Worse [CD]. California: Scotti Brothers Records.

Yankovic, A. (1988b). 'I think I'm a clone now'. Even Worse [CD]. California: Scotti Brothers Records.

Yankovic, A. (1994). [Liner notes]. 'Permanent Record: Al in the Box'. California, United States: Scotti Brothers Records.

Yankovic, A. (2006a). 'Close but no cigar'. Straight Outta Lynwood [CD]. California: Volcano.

Yankovic, A. (2006b). 'Pancreas'. Straight Outta Lynwood [CD]. California: Volcano.

Yankovic, A. (2011a). 'Whatever you like'. Alpocalypse [CD]. California: Volcano.

Yankovic, A. (2011b). 'Craigslist'. Alpocalypse [CD]. California: Volcano.

Yankovic, A. (2011c). 'Skipper Dan'. Alpocalypse [CD]. California: Volcano.

Yankovic, A. (2014a). 'Tacky'. Mandatory Fun [CD]. California: RCA.

Yankovic, A. (2014b). 'Word crimes'. Mandatory Fun [CD]. California: RCA.

Yankovic, A. (2017). 'Brain song'. Medium Rarities [CD]. California: RCA.

Zaru, D. (2017). 'Beyoncé gets political at Super Bowl, pays tribute to "Black Lives Matter"'. Retrieved from https:/www.cnn.com/2016/02/08/politics/beyonce-super-bowl-black-livesmatter/index.htm 
Zolotow, M. (1963, April 20). 'Spoofmaster'. Saturday Evening Post, pp. 26-27.

Ziv, A. (1981). The Psychology of Humor. Tel Aviv: Yahdav.

Ziv, A. (1988). 'Teaching and learning with humor: Experiment and replication'. The Journal of Experimental Education 57 (1), pp. 4-15.

Zurek, W. H. (2000). 'Quantum cloning: Schrodinger's sheep'. Nature 404 (6774), pp. 130-132. doi: $10.1038 / 35004684$ 